\title{
Faktor-Faktor yang Berhubungan dengan Masalah Tidur Remaja Selama Pandemi Covid-19
}

\author{
Sri Hartini, Khairun Nisa, ${ }^{1}$ Elisabeth Siti Herini ${ }^{2}$ \\ ${ }^{1}$ Magister Keperawatan, ${ }^{2}$ Departemen Ilmu Kesehatan Anak Fakultas Kedokteran, Kesehatan Masyarakat, dan Keperawatan Universitas \\ Gadjah Mada, Yogyakarta
}

Latar belakang. Masalah tidur pada remaja selama pandemi Covid-19 dilaporkan sekitar 20-66\%. Rendahnya dukungan sosial, gangguan akademik dan kesehatan fisik yang menurun, paparan informasi, pengetahuan dan sikap tentang kesehatan tidur berhubungan dengan masalah tidur dan kebiasaan tidur pada remaja.

Tujuan. Tujuan penelitian ini untuk mengetahui gambaran masalah tidur remaja dan faktor yang berhubungan selama pandemi Covid-19.

Metode. Penelitian ini menggunakan desain cross-sectional. Seratus empat (104) remaja berusia 12-15 tahun di Kecamatan Samaturu, Kabupaten Kolaka, Sulawesi Tenggara di rekruit menjadi responden penelitian. Sleep Disturbance Scale for Children (SDSC), kuesioner pengetahuan dan sikap tentang tidur digunakan untuk mengukur masalah tidur, pengetahuan dan sikap tentang tidur. Uji regresi linear digunakan untuk menganalisis faktor-faktor yang berhubungan dengan tidur remaja.

Hasil. Prevalensi masalah tidur pada remaja selama pandemi Covid-19 sebesar 78\%. Gangguan transisi tidur bangun merupakan jenis masalah tidur yang paling tinggi ditemukan (53\%). Pengetahuan dan sikap tentang tidur berhubungan dengan masalah tidur remaja selama pandemik Covid-19.

Kesimpulan. Sebagian besar remaja berusia 12-15 tahun mengalami masalah tidur selama pandemi Covid-19. Faktor yang paling dominan berhubungan dengan masalah tidur adalah sikap remaja tentang kesehatan tidur. Sari Pediatri 2021;22(5):311-7

Kata kunci: masalah tidur, remaja, pengetahuan, sikap, Covid-19

\section{Factors Correlating with Sleep Disorders among Adolescents during The Covid-19 Pandemic}

\begin{abstract}
Sri Hartini, Khairun Nisa, ${ }^{1}$ Elisabeth Siti Herini ${ }^{2}$
Background. Sleep disorders have been found among 20-66\% of adolescents during the Covid-19 pandemic. Low social support, academic impairment, decrease of physical health, exposure to information, knowledge, and attitudes towards sleep health correlate with sleep disorders and sleep habits among adolescents.

Objectives. This study aimed to describe sleep disorders among adolescents and to identify the correlating factors during the Covid-19 pandemic.

Method. This research used a cross-sectional design. One hundred and four (104) adolescents aged 12-15 in Samaturu Sub-district, Kolaka Regency, Southeast Sulawesi served as respondents. Sleep disturbance scale for children (SDSC) and questionnaires about knowledge and attitudes towards sleep were employed to measure sleep disorders, knowledge, and attitudes towards sleep health. The linear regression test was used to analyze the factors correlating with sleep among adolescents.

Results. During the Covid-19 pandemic, the prevalence of sleep problems among adolescents is as much as $78 \%$. Sleep-wake transition disorder is the most frequent type of disorder (53\%). Knowledge and attitudes towards sleep correlate with sleep disorders among adolescents during the Covid-19 pandemic.

Conclusion. Most adolescents aged 12-15 experienced sleep disorders during the Covid-19 pandemic. The most dominant factor correlating with sleep disorders is the attitudes towards sleep health.Sari Pediatri 2021;22(5):311-7
\end{abstract}

Keywords: sleep disorders, adolescents, knowledge, attitudes

Alamat korespondensi: Sri Hartini. Departemen Keperawatan Fakultas Kedokteran Kesehatan Masyarakat, dan Keperawatan UGM Jl. Farmako, Sekip, Yogyakarta 55281. Email: srihartini.psik@ugm.ac.id 
Sri Hartini dkk: Faktor-Faktor yang berhubungan dengan masalah tidur remaja selama pandemi Covid-19

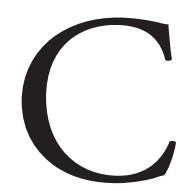

oronavirus disease 2019 (Covid-19) pertama kali muncul pada bulan Desember 2019 di Wuhan, Hubei, Cina dengan gambaran klinis yang sangat mirip dengan penyakit pneumonia. ${ }^{1}$ Pengalaman hidup selama pandemi dapat menyebabkan masalah tidur pada beberapa orang dan juga dapat memperburuk gejala pada mereka yang telah mengalami masalah tidur. ${ }^{2}$

Prevalensi masalah tidur pada remaja di masa pandemi Covid-19 telah dilaporkan dalam suatu survei di Cina dan ditemukan 20,1\% dari 320 anak dan remaja memiliki masalah tidur. ${ }^{3}$ Selain itu, penelitian yang dilakukan oleh $\mathrm{Li} \mathrm{dkk}^{4}$ dengan melakukan survei melalui facebook terhadap 1970 responden menyebutkan $55,8 \%$ responden melaporkan memiliki gangguan tidur. Masalah tidur seringkali tidak disadari oleh remaja usia 13-17 tahun, didapatkan $66 \%$ memiliki masalah tidur, tetapi hanya sepertiga dari jumlah tersebut yang dapat mengidentifikasi diri mereka memiliki masalah tidur. ${ }^{5}$

Pada masa pandemi Covid-19, beberapa faktor yang memengaruhi gangguan tidur adalah peningkatan kekhawatiran tentang Covid-19, dukungan sosial yang rendah, gangguan akademik, dan kesehatan fisik yang menurun. ${ }^{4}$ Selain itu, beberapa penelitian juga menyebutkan faktor usia, jenis kelamin, status ekonomi, paparan informasi tentang tidur berpengaruh terjadinya masalah tidur pada remaja. Masalah tidur dikaitkan dengan usia yang bertambah pada remaja. Masalah tidur lebih sering dialami oleh remaja perempuan dibanding remaja laki-laki. ${ }^{6}$ Penelitian lain menyebutkan bahwa tidak ada perbedaan gender yang signifikan terhadap masalah tidur. ${ }^{7}$ Status ekonomi menjadi salah satu faktor penentu kesehatan seseorang.

Menurut Perales \& Plage, ${ }^{8}$ status sosial ekonomi berpengaruh terhadap kebiasaan tidur yang sehat, kualitas tidur dan masalah tidur. Paparan informasi tentang tidur melalui teknologi digital memberikan peluang yang bisa membantu meningkatkan sikap dan perilaku untuk tidur yang lebih baik. ${ }^{9}$ Paparan informasi tentang tidur yang kurang baik menyebabkan kurangnya pengetahuan dan sikap tidur. Keduanya berkontribusi terhadap kebiasaan tidur yang buruk dan menurunkan total durasi tidur. ${ }^{10,11}$ Masalah tidur memiliki dampak terhadap status kesehatan, seperti depresi, obesitas dan risiko kecelakaan mengemudi pada ramaja. ${ }^{12}$ Tujuan dari penelitian ini adalah untuk mengetahui faktor-faktor yang berhubungan dengan tidur remaja di masa pandemi Covid-19.

\section{Metode}

Penelitian ini adalah penelitian deskriptif korelatif dengan desain cross-sectional yang dilaksanakan pada Bulan April - Juni 2020. Seratus empat remaja di Kecamatan Samaturu, Kabupaten Kolaka, Sulawesi Tenggara direkrut menjadi responden penelitian. Kriteria inklusi responden penelitian adalah remaja berusia 12-15 tahun yang tinggal di Kecamatan Samaturu selama pandemi Covid-19. Sementara kriteria eksklusi adalah remaja yang tidak bersedia menjadi responden penelitian dan mengonsumsi obat yang menyebabkan kantuk. Pengumpulan data dilakukan setelah responden menandatangani informed consent. Instrumen yang digunakan pada penelitian ini terdiri dari sleep disturbance scale for children (SDSC), kuesioner sikap dan kuesioner pengetahuan.

Instrumen SDSC adalah instrumen yang digunakan untuk mengukur masalah tidur. Instrumen SDSC dalam bahasa Indonesia telah divalidasi dan dinilai reliabilitasnya. Nilai sensitivitas dan spesifisitas merupakan instrumen skrining gangguan tidur pada anak sekolah lanjutan tingkat pertama. Spesifisitas SDSC adalah 71,4\% dan 54,5\% dan dapat digunakan sebagai alat skrining gangguan tidur pada remaja. ${ }^{13}$ Pengisian SDSC dilakukan oleh anak dengan pendampingan orang tua di rumah. Anak memilih kolom "selalu" apabila pertanyaan dialami oleh anak setiap hari, anak memilih "sering" apabila pertanyaan dialami 3-5 kali per minggu, anak memilih "kadang-kadang" apabila dialami 1-2 kali per minggu, anak memilih "jarang" apabila pertanyaan dialami 1-2 kali per bulan atau kurang dan anak memilih "tidak pernah" jika tidak mengalami hal tersebut. Instrumen SDSC terdiri dari 26 pertanyaan yang mengukur masalah tidur selama 6 bulan sebelumnya. Skor gangguan tidur memiliki rentang 26 hingga 130. Remaja dikatakan memiliki masalah tidur jika jumlah nilai total keseluruhan domain adalah lebih dari $39 .{ }^{14}$ Penilaian gangguan tidur untuk penegakan diagnosis pada tiap domain masalah tidur adalah dengan melihat T score pada tiap domain. Anak dikatakan memiliki masalah tidur jika nilai T skornya lebih besar dari $70 .{ }^{15}$ Remaja dikatakan memiliki masalah tidur pada domain 
gangguan memulai dan mempertahankan tidur jika jumlah nilai total pada nomor soal kuesioner $(1,2,3$, $4,5,10,11)$ lebih dari 16 , memiliki masalah tidur pada domain gangguan pernapasan saat tidur jika jumlah nilai total pada nomor soal kuesioner $(13,14,15)$ lebih dari 6, memiliki masalah tidur pada domain gangguan kesadaran jika jumlah nilai total pada nomor soal kuesioner $(17,20,21)$ lebih dari 5, memiliki masalah tidur pada domain gangguan transisi tidur -bangun jika jumlah nilai total pada nomor soal kuesioner $(6,7,8$, $12,18,19)$ lebih dari 13 , memiliki masalah tidur pada domain gangguan somnolen berlebihan jika jumlah nilai total pada nomor soal kuesioner $(22,23,24,25$, 26) lebih dari 12 , memiliki masalah tidur pada domain gangguan hiperhidrosis saat tidur jika jumlah nilai total pada nomor soal kuesioner $(9,16)$ lebih dari 6 .

Kuesioner pengetahuan adalah kuesioner yang digunakan untuk mengukur pengetahuan disusun oleh tim peneliti yang terdiri dari 7 domain, yaitu definisi, karakteristik tidur pada remaja, manfaat tidur, dampak kurang tidur, masalah tidur, faktor penyebab gangguan tidur, dan manajemen tidur. Hasil validitas kuesioner pengetahuan menunjukkan nilai r pada rentang 0,3780,723 yang berarti item pertanyaan valid karena nilai $r$ hitung lebih dari nilai $r$ tabel $(0,25)$ dan nilai reliabilitas yang baik dengan nilai 0,79 . Daftar pertanyaan dalam kuesioner dibuat dalam bentuk pertanyaan pilihan ganda dengan bentuk pilihan a, b, c dan d. Interpretasi jawaban menggunakan skala Guttman, yaitu benar dan salah. Jawaban benar diberi nilai 1 dan jawaban salah diberi nilai 0 . Hasil penilaian dari kuesioner dengan rentang nilai $0-13$. Pada penelitian ini pengetahuan dikategorikan menggunakan teori Bloom yang terbagi menjadi 3 kategori dengan cut off poin yang telah dimodifikasi oleh peneliti, yaitu pengetahuan dengan kategori tinggi jika skor yang didapatkan $80-100 \%$ (10-13), pengetahuan kategori sedang 50-79\% (6-9) dan pengetahuan kategori rendah $<50 \%(<6) .{ }^{16}$

Kuesioner sikap adalah kuesioner yang digunakan untuk mengukur sikap dan disusun oleh peneliti berdasarkan teori tentang tidur dari berbagai referensi. Instrumen ini memiliki 6 domain, yaitu karakteristik tidur pada remaja, manfaat tidur, dampak kurang tidur, masalah tidur, faktor penyebab masalah tidur dan manajemen masalah tidur. Hasil validitas konstruk kuesioner sikap tidur yang terdiri dari 16 pertanyaan dengan nilai $r$ hitung $0,275-0,813$ yang berarti item pertanyaan valid karena nilai $r$ hitung lebih dari nilai r tabel $(0,254)$. Nilai reliabilitas kuesioner sikap remaja tentang tidur dalam katagori baik (Cronbach Alpha $=0,885)$. Pilihan jawaban dalam skala likert, yaitu untuk pertanyaan favorable $4=$ sangat setuju, $3=$ setuju, $2=$ tidak setuju, $1=$ sangat tidak setuju. Pertanyaan unfavorable $4=$ sangat tidak setuju, $3=$ tidak setuju, $2=$ setuju, $1=$ sangat setuju. Hasil penilaian dari kuesioner dengan rentang nilai 16-64. Semakin tinggi skor sikap menunjukkan sikap remaja terhadap tidur semakin baik.

Uji Pearson Product Moment digunakan untuk melihat hubungan pengetahuan, sikap dengan masalah tidur remaja. Uji Independent T-Test digunakan untuk menguji hubungan antara jenis kelamin, paparan informasi dengan masalah tidur. One way anova digunakan untuk menguji hubungan antara usia dengan masalah tidur remaja. Variabel yang memiliki $\mathrm{p}<0,25$ dimasukkan ke dalam analisis multivariat. Uni regresi linear digunakan untuk mengetahui faktor yang berhubungan dengan tidur remaja selama pandemi Covid-19

Penelitian ini telah mendapatkan persetujuan etik dari Komisi etik Fakultas Kedokteran, Kesehatan Masyarakat, dan Keperawatan, Universitas Gadjah Mada dengan nomor etik: KE/FK/0332/EC/2020.

\section{Hasil}

Jumlah responden penelitian adalah 104 remaja dengan distribusi lebih banyak remaja putri (65,7\%). Rerata usia responden adalah $13,51 \pm 0,94$ yang terdiri dari $12,4 \%$ remaja usia 12 tahun, 38,1\% remaja usia 13 tahun, 28,6\% remaja usia 14 tahun, dan 20\% remaja usia 15 tahun. Terdapat 77,1\% remaja belum pernah mendapatkan paparan informasi terkait kesehatan tidur. Sebagian besar responden $(81 \%)$ berasal dari keluarga dengan pendapatan di bawah Upah Minimum Kerja (UMK).

Sebagian besar responden $(78,1 \%)$ mengalami masalah tidur selama pandemi. Masalah paling banyak dialami oleh remaja selama pandemi adalah gangguan transisi tidur-bangun (Tabel 1).

Pada penelitian ini kami menemukan bahwa mengantuk pada siang hari, kaki remaja sering tersentak ketika tidur, remaja melakukan gerakan berulang-ulang ketika mengalami kesulitan untuk bangun merupakan lima perilaku tidur terbanyak yang sering dan selalu dialami oleh remaja. 
Uji bivariat menunjukkan terdapat hubungan negatif antara sikap dengan masalah tidur remaja selama pandemi Covid-19. Hal ini berarti bahwa

Tabel 1. Masalah tidur remaja selama $(\mathrm{n}=104)$

\begin{tabular}{lcc}
\hline Domain & \multicolumn{2}{c}{ Masalah tidur } \\
\cline { 2 - 3 } & $\begin{array}{c}\text { Ya } \\
(\mathrm{f} / \%)\end{array}$ & $\begin{array}{c}\text { Tidak } \\
(\mathrm{f} / \%)\end{array}$ \\
\hline $\begin{array}{l}\text { Problem of starting and } \\
\text { maintaining sleep }\end{array}$ & $32(30,5 \%$ & $72(6,6)$ \\
Respiratory distress during sleep & $16(15,2)$ & $88(83,8)$ \\
Consciousness disorder & $22(21)$ & $82(78,1)$ \\
Sleep-wake transitional disorder & $53(50,5)$ & $51(48,6)$ \\
Excessive somnolence disorder & $37(35,2)$ & $67(63,8)$ \\
Hyperbidrosis disorder & $15(14,3)$ & $89(84,8)$ \\
\hline
\end{tabular}

f: frekuensi; UMK: upah minimum Kota/Kabupaten semakin baik sikap terhadap tidur, maka masalah tidur remaja semakin sedikit. Tidak ada hubungan bermakna antara jenis kelamin, usia, pendapatan keluarga, paparan informasi dan pengetahuan dengan masalah tidur remaja selama pandemi (Tabel 2).

Analisis multivariat dimulai dengan melakukan seleksi kandidat uji multivariat pada variabel yang memiliki $\mathrm{p}<0,25$. Variabel bebas yang memenuhi syarat sebagai kandidat multivariat adalah variabel paparan informasi $(0,22)$, pengetahuan $(0,12)$, dan sikap $((0,019)$. Ketiga variabel bebas tersebut kemudian dianalisis dengan menggunakan uji regresi linear dengan metode backward. Variabel yang secara signifikan memengaruhi masalah tidur remaja selama pandemi Covid-19 tertera pada Tabel 3. Nilai yang digunakan untuk mengidentifikasi faktor yang paling dominan memengaruhi masalah tidur remaja adalah

Tabel 2. Hubungan karateristik, pengetahuan, sikap dengan masalah tidur remaja

\begin{tabular}{|c|c|c|c|}
\hline \multirow{2}{*}{ Karakteristik responden } & \multicolumn{2}{|c|}{ Masalah tidur } & \multirow[t]{2}{*}{$\mathrm{p}$} \\
\hline & Mean \pm SD & $\mathrm{r}$ & \\
\hline \multicolumn{4}{|l|}{ Jenis kelamin } \\
\hline Laki-laki & $55,51 \pm 9,67$ & & 0,76 \\
\hline Perempuan & $54,89 \pm 9,68$ & & \\
\hline Usia & & $13,51 \pm 0,94$ & 0,48 \\
\hline \multicolumn{4}{|l|}{ Pendapatan } \\
\hline Di atas UMK & $54,47 \pm 10,30$ & & 0,75 \\
\hline Di bawah UMK & $55,24 \pm 9,53$ & & \\
\hline \multicolumn{4}{|l|}{ Paparan Informasi } \\
\hline Ya & $52,95 \pm 8,05$ & & 0,22 \\
\hline Tidak & $55,71 \pm 10,00$ & & \\
\hline Pengetahuan & & $-0,15$ & 0,125 \\
\hline Sikap & & $-0,229^{*}$ & 0.019 \\
\hline
\end{tabular}

SD: Standar deviasi; r : koefisien korelasi; p: signifikansi; UMK: upah minimum Kota/Kabupaten

Tabel 3. Faktor yang berhubungan dengan masalah tidur remaja selama pandemik COVID-19 ( $\mathrm{n}=104)$

\begin{tabular}{lcccc}
\hline Model & $\begin{array}{c}\text { Unstandardized } \\
\text { Coefficients }\end{array}$ & $\begin{array}{c}\text { Standardized } \\
\text { Coefficients }\end{array}$ & $\mathrm{p}$ & $\begin{array}{c}\text { Adjusted R } \\
\text { Square }\end{array}$ \\
\hline (Constant) & 64,39 & $\beta$ & & 0,000 \\
$\quad$ Paparan informasi & 1,80 & 0,78 & 0,42 & \\
Pengetahuan & $-0,60$ & $-0,16$ & 0,10 & \\
Sikap & $-0,23$ & $-0,24$ & 0,01 & \\
(Constant) & 68,16 & & 0,000 & 0,066 \\
$\quad$ Pengetahuan & $-0,67$ & $-0,17$ & 0,06 & \\
Sikap & $-0,23$ & $-0,24$ & 0,01 & \\
\hline
\end{tabular}

Signifikan dengan $\mathrm{p}<0,05 ;$ Adjusted $R$ Square 6\% 
nilai p dan nilai standardized coefficients beta $(\beta)$. Hasil analisis pemodelan 2 menunjukkan 0,24 yang berarti bahwa pengetahuan dan sikap adalah variabel yang memengaruhi masalah tidur remaja. Sementara variabel yang paling dominan adalah sikap remaja karena memiliki nilai $\beta 0,24$. Konstanta sebesar 68,16 memiliki arti jika kedua variabel (pengetahuan dan sikap) bernilai 0 maka nilai masalah tidur remaja bernilai 68,16. Nilai Adjusted $R^{2}$ menunjukkan bahwa pengetahuan dan sikap untuk menjelaskan masalah tidur sebesar $6 \%$.

\section{Pembahasan}

Hasil penelitian menunjukkan bahwa $78 \%$ remaja mengalami masalah tidur selama pandemi Covid-19. Beberapa hasil penelitian terhadap remaja sebelum pandemi Covid-19 menunjukkan masalah tidur remaja di Jakarta Timur sebesar 62,9. ${ }^{17}$ Natalita $^{13}$ melaporkan hasil serupa, 62,5\% remaja di Bekasi mengalami masalah tidur. Kami menemukan bahwa masalah tidur pada remaja lebih tinggi selama pandemi Covid-19 dibandingkan sebelum pandemi Covid-19. Kemungkinan ini diasumsikan karena selama pandemi Covid-19, remaja mengalami penurunan aktivitas atau interaksi sosial dengan teman sebaya dan lingkungan sekolah karena dampak penerapan social dan physical distancing. Hal ini konsisten dengan penelitian Yeasmin $\mathrm{dkk}^{18}$ melaporkan bahwa gangguan tidur, kecemasan, dan depresi merupakan dampak dari pandemi Covid-19. Pandemi Covid-19 berhubungan dengan tidur berlebihan pada anak dan remaja. ${ }^{19}$ Selama pandemi Covid-19, terjadi perubahan pola hidup pada remaja yang lebih banyak menghabiskan waktu di rumah dengan menjaga jarak sosial. Selain itu Moore $\mathrm{dkk}^{20}$ juga melaporkan bahwa anak dan remaja mengalami penurunan yang signifikan terhadap aktivitas fisik pada masa pandemi, sedangkan penggunaan media sosial dilaporkan jauh lebih tinggi dari pada sebelum pandemi. Penggunaan media sosial khususnya di malam hari secara signifikan menyebabkan masalah tidur pada remaja. ${ }^{21}$

Hasil penelitian masalah tidur di Brazil dan Portugis selama pandemi Covid-19 dilaporkan sebesar $42,7 \% .^{22}$ Zhou dkk ${ }^{23}$ melaporkan hasil serupa bahwa terdapat $23,2 \%$ dari 11,835 remaja di Cina mengalami masalah tidur dengan insomnia. Selain itu, masalah tidur juga dialami oleh $20,1 \%$ remaja. $^{3}$ Masalah tidur remaja di Indonesia dan Cina selama pandemi Covid-19 berbeda karena prevalensi masalah tidur sebelum pandemi Covid-19 di Cina lebih rendah dibandingkan di Indonesia sebelum pandemi Covid-19. Insomnia dan kualitas tidur buruk dialami oleh $16,1 \%$ sampai $18,8 \%$ remaja di Cina.

Hasil penelitian kami menunjukkan bahwa jenis masalah tidur yang paling banyak dialami oleh remaja selama pandemi Covid-19 adalah gangguan transisi tidur-bangun. Hal ini sejalan dengan laporan orang tua di Brazil dan Portugis yang menyatakan bahwa terdapat perubahan transisi tidur-bangun pada anaknya selama social distancing masa pandemi Covid-19.22 Hasil penelitian lain yang serupa menyatakan bahwa $62,9 \%$ remaja mengalami gangguan transisi tidur-bangun. ${ }^{23}$ Herdiman $\mathrm{dkk}^{24}$ juga melaporkan $43,4 \%$ remaja di Semarang mengalami gangguan transisi tidur-bangun dan merupakan gangguan tidur terbanyak yang dialami oleh remaja.

Anak mengantuk pada siang hari adalah perilaku tidur terbanyak yang sering dan selalu dialami oleh remaja. Kantuk pada siang hari merupakan masalah tidur yang sering terjadi pada remaja. ${ }^{25}$ Sebagian besar remaja tidak mendapatkan jumlah tidur yang cukup sesuai dengan rekomendasi, yaitu 8-10 jam permalam sehingga hal ini menjadi penyebab sebagian besar remaja memiliki rasa kantuk pada siang hari. ${ }^{26}$ Data dari National Sleep Foundation (NSF) 2006 dalam Owens $\mathrm{dkk}^{27}$ melaporkan hanya 20\% dari 253 remaja memiliki durasi tidur yang disarankan. Peningkatan kantuk pada siang hari juga dilaporkan oleh remaja India selama pandemi Covid dan lock down. ${ }^{28}$ Hasil ini konsisten dengan penelitian yang dilakukan di Cina yang melaporkan bahwa prevalensi kantuk di siang hari dialami oleh $64,4 \%$ anak dan yang menyatakan selalu mengantuk pada siang hari sebanyak $26,9 \%$.

Kaki remaja tersentak ketika tertidur adalah perilaku tidur terbanyak kedua yang sering dan selalu dialami oleh remaja. Kondisi ini sering disebut dengan restless legs syndrome (RLS). Pada penelitian kami, remaja yang sering mengalami RLS sebesar 20\% dari 104 remaja. Giannaki ${ }^{29}$ melaporkan prevalensi RLS di Negara Cyprus sebesar 5,1 \% dari 157 remaja. Kualitas tidur yang terganggu akibat RLS dapat memengaruhi kesehatan psikososial pada remaja.

Remaja melakukan gerakan berulang ketika tidur merupakan perilaku tidur terbanyak ketiga yang sering dan selalu dialami oleh remaja. Menurut American 
Sri Hartini dkk: Faktor-Faktor yang berhubungan dengan masalah tidur remaja selama pandemi Covid-19

Academy of Sleep Medicine, 2005 dalam Gupta $\mathrm{dkk}^{30}$ kondisi ini disebut sleeprelated rhythmic movement disorders (RMDs) yang ditandai dengan gerakan tubuh bergoyang, menggerakkan kepala, menggulung kepala, badan atau kaki dan membenturkan kaki saat tidur. Hasil penelitian ini menyebutkan 20\% dari 104 remaja sering mengalami keadaan tersebut. Menurut Merlino \& Gigli $^{31}$ kondisi ini dapat menyebabkan kualitas tidur yang buruk, kelelahan dan kantuk yang berlebihan pada siang hari.

Remaja merasa mimpi seperti nyata ketika tertidur merupakan perilaku tidur terbanyak keempat yang sering dan selalu dialami. Keadaan ini merupakan gejala dari masalah tidur dengan gangguan transisi saat tidur yang biasa disebut dengan hypnagogic hallucinations, yaitu persepsi abnormal yang terjadi saat tidur. ${ }^{32}$ Penelitian ini menyebutkan 26,7\% remaja mengalami keadaan ini. Waters $\mathrm{dkk}^{33}$ menyebutkan hypnagogic hallucinations ditemukan sekitar $70 \%$ dari jumlah populasi umum.

Sangat sulit untuk bangun tidur merupakan perilaku tidur terbanyak kelima yang sering dan selalu dialami oleh remaja. Sulit untuk terbangun dari tidur merupakan salah satu tanda remaja mengalami masalah tidur dengan insomnia. ${ }^{34}$ Kejadian insomnia pada remaja terjadi sekitar 10-20\% yang dipengaruhi oleh beberapa faktor, seperti jenis kelamin dan kejadian pubertas, stres sekolah, penggunaan media sosial, dan peningkatan konsumsi kafein. ${ }^{35}$ Masalah tidur yang sering terjadi pada remaja adalah insomnia dan hasil dari penelitian ini menyebutkan 21\% dari 104 remaja sulit untuk bangun dari tidur. ${ }^{25}$

Hasil penelitian ini menunjukkan masalah tidur berhubungan dengan sikap remaja terhadap tidur. Variabel sikap remaja juga merupakan faktor yang paling dominan yang berhubungan dengan masalah tidur remaja. Pengetahuan dan sikap yang tidak memadai tentang tidur berkontribusi terhadap kebiasaan tidur yang buruk dan menurunkan total durasi tidur. ${ }^{10,11}$ Sebaliknya, sikap remaja yang baik terhadap tidur berkontribusi terhadap kualitas tidur yang baik.

\section{Kesimpulan}

Pengetahuan dan sikap merupakan faktor yang berhubungan dengan masalah tidur remaja berusia 1215 tahun selama pandemi Covid-19. Sikap merupakan faktor yang paling dominan yang berhubungan dengan masalah tidur remaja berusia $12-15$ tahun selama pandemi Covid-19.

\section{Konflik Kepentingan}

Tidak ada konflik kepentingan dalam penelitian ini.

\section{Ucapan terima kasih}

Kami ucapkan terima kasih kapada Universitas Gadjah Mada yang telah membantu pendanaan dalam penelitian ini. Selain itu terima kasih kami sampaikan kepada remaja yang telah berkontribusi dalam penelitian ini.

\section{Daftar pustaka}

1. Huang C, Wang Y, Li X, dkk. Clinical features of patients infected with 2019 novel coronavirus in Wuhan, China. Lancet 2020;395(10223): 497-506.

2. Lin L, Wang J, Ou-yang X, dkk. The immediate impact of the 2019 novel coronavirus (COVID-19) outbreak on subjective sleep status. Sleep Med https://doi.org/10.1016/j. sleep.2020.05.018.

3. Jiao WY, Wang LN, Liu J, dkk. Behavioral and emotional disorder in children during the COVID-19 Epidemic. J Pediatr 2020;221:164-266.

4. Li DJ, Ko NY, Chen YL, dkk. Covid-19-related factors associated with sleep disturbance and suicidal thoughts among the taiwanese public: A facebook survey. Int J Environ Res Pub Health 2020;17:1-12.

5. Short MA, Gradisar M, Gill J, Camfferman D. Identifying adolescent sleep problems. Plos One 2013;8:1-6.

6. Amaral O, Pereira C, Veiga N, Coutinho E, Chaves C, Nelas P. Gender and age differences in the sleep habits : a cross-sectional study in adolescents. Aten Prim 2016;48:178-82.

7. Tremaine RB, Dorrian J, Blunden S. Subjective and objective sleep in children and adolescents: Measurement, age, and gender differences. Sleep Biol Rhythms 2010; 8:229-38.

8. Perales, F, Plage S. Losing ground, losing sleep: Local economic conditions, economic vulnerability, and sleep. Soc Sci Res 2017;62:189-203.

9. Knowlden AP, Sharma M, Bernard AL. A Theory of planned behavior research model for predicting the sleep intentions and behaviors of undergraduate college students. J Primary Prevent 2012;33:19-31.

10. Rigney G, Blunden S, Maher C, dkk. Can a school-based sleep education programme improve sleep knowledge, hygiene and 
behaviours using a randomised controlled trial. Sleep Med 2015;16:736-45.

11. Jin L, Zhou J, Peng H, Ding S, Yuan H. Investigation on Dysfunctional Beliefs and Attitudes About Sleep in Chinese College Students. Neuropsych Dis Treat 2018;14 :1425-32

12. Village EG. Insufficient sleep in adolescents and young adults : an update on causes and consequences. Pediatrics 2014;134:e921-e32.

13. Natalita C, Sekartini R, Poesponegoro H. Skala gangguan tidur untuk anak (SDSC) sebagai instrumen skrining gangguan tidur pada anak sekolah lanjutan tingkat pertama. Sari Pediatri 2016;12:365-72.

14. Bruni O, Ottaviano S, Guidetti V, dkk. The sleep disturbance scale for children (SDSC) construction and validation of an instrument to evaluate sleep disturbances in childhood and adolescence. J Sleep Res 1996;5:251-61.

15. Schurman JV, Friesen CA, Dai H, Danda CE, Hyman PE, Cocjin JT. Sleep problems and functional disability in children with functional gastrointestinal disorders: an examination of the potential mediating effects of physical and emotional symptoms. BMC Gastroenterol 2012;12:1-11.

16. Seid MA, Hussen MS. Knowledge and attitude towards antimicrobial resistance among final year undergraduate paramedical students at University of Gondar, Ethiopia. BMC Infect Dis 2018;18:1-8.

17. Haryono A, Rindiarti A, Arianti A, dkk. Prevalensi gangguan tidur pada remaja usia 12-15 tahun di sekolah lanjutan tingkat pertama. Sari Pediatri 2009;11:149-54.

18. Yeasmin S, Banik R, Hossain S, dkk. Impact of COVID-19 pandemic on the mental health of children in Bangladesh: A cross-sectional study. Child Youth Serv Rev 2020;117:1-7.

19. Becker SP, Gregory AM. Editorial Perspective: Perils and promise for child and adolescent sleep and associated psychopathol ogy during the COVID-19 pandemic. J Child Psychol Psyc 2020; 61:757-9.

20. Moore SA, Faulkner G, Rhodes RE, dkk. Impact of the COVID-19 virus outbreak on movement and play behaviours of Canadian children and youth: a national survey. Int J Behav Nutr Phy 2020;17:1-11.

21. Woods HC, Scott H. Sleepyteens: social media use in adolescence is associated with poor sleep quality, anxiety, depression and low self-esteem. J Adolesc 2016;51:41-9.

22. Baptista AS, Prado IM, Perazzo MF, dkk. Can children's oral hygiene and sleep routine be compromised during the OVID-19 Pandemic? Int J Paediatr Dent 2020. doi: 10.1111/ipd.12732.

23. Zhou S, Wang L, Yang R, Yang X, Zhang L. COVID-19 treatment: close to a cure? A rapid review of pharmaco therapies for the novel corona virus (SARS-CoV-2). Int J Antimicrob Agents 2020;59:1-8.

24. Herdiman A, Hartanto F, Hendrianingtyas M. Hubungan gangguan tidur terhadap prestasi belajar pada remaja usia 12 15 tahun di Semarang: studi pada siswa SMPN 5 Semarang. Jurnal Kedok Diponegoro 2015;4: 327-35.

25. Gradisar M, Gardner G, Dohnt H. Recent worldwide sleep patterns and problems during adolescence : A review and metaanalysis of age , region, and sleep. Sleep Med 2011;12:110-18.

26. Moore M, Meltzer LJ. The sleepy adolescent: causes and consequences of sleepiness in teens. Paediatr Respir Rev 2008;9:114-21.

27. Owens JA, Jones C, Nash R. Caregivers' knowledge, behavior, and attitudes regarding healthy sleep in young children. J Clin Sleep Med 2011;7:7-12.

28. Manjumdar P, Biswas A, Sahu S. Covid-19 pandemic and locdown: cause of sleep duration, depression, somatic pain, and increased screen exposure of office worker and students of India. Chronobiol Int 2020;37:1191-200.

29. Giannaki CD, Hadjigeorgiou GM, Aphamis G, Pantzaris M, Sakkas GK. Restless legs syndrome in adolescents: Relationship with sleep quality, cardiorespiratory fitness and body fat. Sleep Sci 2017;10:7-10.

30. Gupta R, Goel D, Dhyani M, Mittal M. Head banging persisting during adolescence: A case with polysomnographic findings. J Neurosci Rural Pract 2014;5:405-8.

31. Merlino G, Gigli GL. Sleep-related movement disorders. Neurol Sci 2012;33:491-513.

32. Goswami M, Pandi-Perumal SR, Thorpy MJ. Narcolepsy: A Clinical Guide. Sleep 2010;33:1261

33. Waters F, Blom JD, Dang-Vu TT, dkk. What is the link between hallucinations, dreams, and hypnagogic-hypnopompic experiences?. Schizophr Bull 2016;42:1098-109.

34. Kaneita Y, Ohida T, Osaki Y dkk. Insomnia among Japanese adolescents: A nationwide representative survey. Sleep 2006;29:1543-50.

35. Zambotti M, De GA, Colrain IM, Baker FC. Insomnia disorder in adolescence: Diagnosis, impact, and treatment. Sleep Med Rev 2018;39:12-24. 